\title{
Gabal El Fereyid - Wadi Rahaba Area, South Eastern Desert, Egypt: Mineralization and Spectrometric Prospecting
}

\author{
Gehad M. Saleh ${ }^{1 *}$, Maher I. Dawoud ${ }^{2}$, Hassan A. Shahin ${ }^{1}$, Farrage M.Khaleal ${ }^{1} \&$ Bahaa M. $^{2}$ \\ Emad $^{1}$ \\ ${ }^{I}$ Nuclear Materials Authority, P.O. Box 530, El Maadi, Cairo, Egypt. \\ ${ }^{2}$ Geology Department, Faculty of Science, Minufiya University, Egypt.
}

*Corresponding Author: Gehad M. Saleh, Nuclear Materials Authority, P.O. Box 530, El Maadi, Cairo, Egypt.

\begin{abstract}
The present work deals with geology, mineralization and spectrometric prospecting of the granitic rocks associated with pegmatites G. El Fereyid - W. Rahaba area, South Eastern Desert of Egypt. The granitic rocks comprise tonalite, monzogranite and pegmatite occur as a vein type (granitic and perthitic pegmatites) hosted within the monzogranite. Pegmatitic bodies associating the monzogranite contains radioactive minerals such as thorite, uranothorite, samarskite, ishikawaite, and fergusonite, besides the presence of some radioelements-bearing accessory minerals such as; zircon, monazite and fluorite. The high level of radioactivity in pegmatites is attributed to the presence of the radioactive minerals thorite and uranothorite as confirmed by ESME analysis. The uranium and thorium mineralization in the radioactive pegmatite could be regarded as magmatic (syngenetic) as well as hydrothermal (epigenetic). From the D-factor of the monzogranite and pegmatite veins of the G. El Fereyid - W. Rahaba area, it is clear that chemical uranium is more than the radiometric uranium in all of the samples, which reflects disequilibrium due to the addition of uranium. This means that uranium has been transported recently and has not time for decay.
\end{abstract}

Keywords: Mineralaization, Spectrometric prospecting, Pegmatites, G. El Fereyid area, Egypt.

\section{INTRODUCTION}

The investigated area is located at the South Eastern Desert between latitudes $23^{\circ} 15^{\prime} 00^{\prime \prime}-23^{\circ} 30^{\prime} 00^{\prime \prime}$ $\mathrm{N}$ and longitudes $35^{\circ} 15^{\prime} 00^{\prime \prime}-35^{\circ} 30^{\prime} 00^{\prime \prime} \mathrm{E}$ (Fig. 1). The FCC image of band ratios covers a major part of study area (Fig. 2) is used in regional interpretation for general rock units identification and association. Topographically the area is generally characterized by low to moderate relief, but granitic hills form high peaks of relatively high elevation compared to the surrounding other rock units. Uranium mineralogy is complex with approximately 5\% of all known minerals containing uranium as an essential structural constituent (Mandarino, 1999). These minerals display remarkable structural and chemical diversity reflecting the diverse occurrences of uranium in the earths crust (Plant et al., 1999). Uranium is uncommon amongst metallic ore elements by having significant portion of ore minerals that can host uranium in dif- ferent valencies (Fig. 1). In the case of uranium this is as tetravalent or hexavalent uranium (Gorman-Lewis et al., 2008).

Most of the radioactive occurrences in the basement rocks of Egypt are present in the younger granites and associated pegmatites (Abd El Naby and Saleh, 2003). The high level of radioactivity of these rocks is attributed to the presence of accessory minerals like zircon, monazite, thorite, uranothorite and allanite (Shurmann, 1966). Uranium and thorium are generally enriched in the youngest, most felsic and most potassic members of comagmatic suites of igneous rocks (Rogers and Adams, 1969). Although pegmatites have been considered as favorable uranium and thorium environments (Page, 1950), they are equally considered as poor mining targets (Gaberlman, 1977). Radioactive pegmatites have been recorded in many areas in the Eastern Desert of Egypt. Omar (1995) recorded radioactive anomalies associated with pegmatitic bodies of the G. Um Anab, the pegmatitic bodies of the G. Ras Baroud younger granite (Sayyah et al., 1993 and Raslan et al., 2010) and radioactive pegmatites related to the G. El Sibai alkali feldspar granites (Ali, 2001). Ibrahim et al. (1997) recorded uranium and columbite mineralization in the pegmatites related to the G. Abu DOB 
granitoids. Anomalous pegmatites associated with granitic rocks have also been reported in the southern part of the Eastern Desert (Ibrahim et al., 2001). The aim of the present study is to highlights on mineralization and spectrometric prospecting of the monzogranite and pegmatites, G. El Fereyid W. Rahaba area, SED, Egypt.

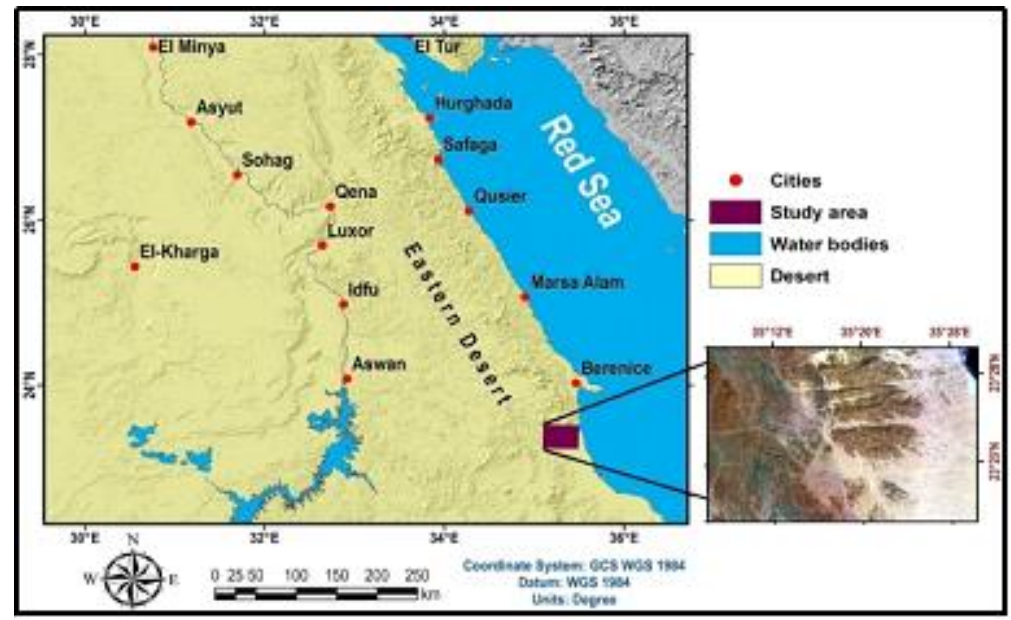

Fig. 1 Location map of G. El Fereyid - W. Rahaba area, South Eastern Desert, Egpyt

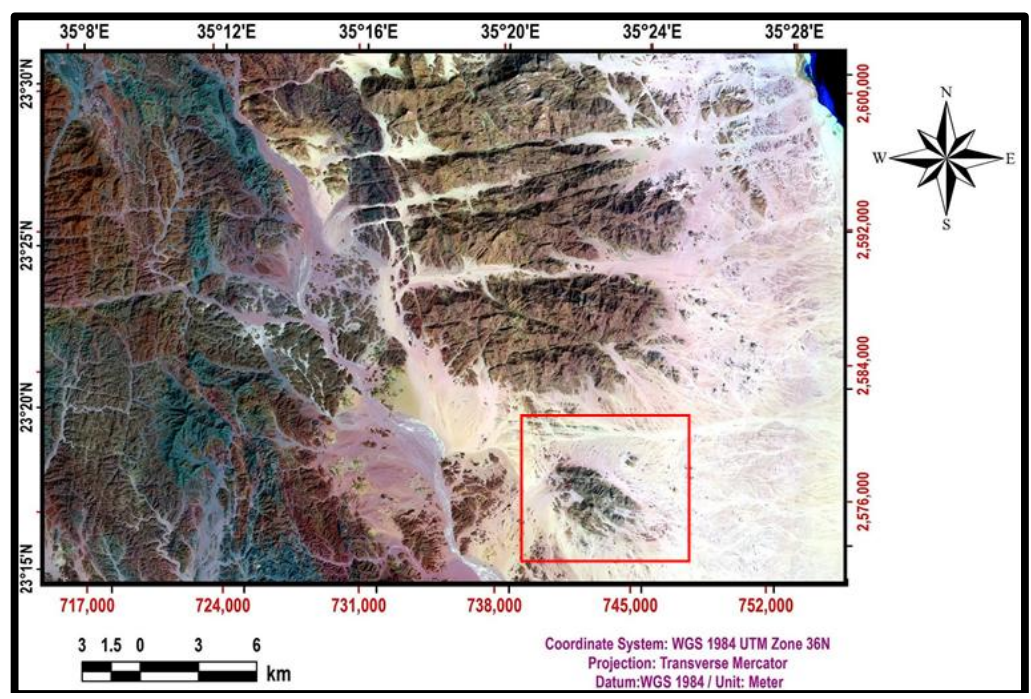

Fig. 2 Landsat FCC (7, 5, 3 bands) ratios image map of G. El Fereyid - W. Rahaba area, South Eastern Desert, Egpyt.

\section{GEOLOGIC SETTING}

The Precambrian basement rocks exposed in G. El Fereyid - W. Rahaba area (El Baraga, 1992, El Amawy, 1991, El Eraqi, 1990, Abdel Karim et al., 2000 and Abd El Naby and Saleh, 2003) represent a part of the Pan-African belt of the Arabian Nubian Shield (Fig. 3). Gneisses represent the oldest rock unit in the mapped area and crop out in the north eastern and south western parts of the mapped area (Fig. 3) and highly eroded forming low hills. Ophiolitic mélange forms the oldest rock unit in the studied area with gneisses. Ophiolitic mélange of the study area consists of mixture of blocks and masses of varies dimensions of serpentinites and metagabbros. Metavolcanics crop out in the central part of the mapped area as relatively elongate in shape trending roughly in $\mathrm{N}-\mathrm{S}$ direction moderately to low relief at G. Urga and G. Um Tineidba areas (Fig. 3). Quartz diorite association form elongated belts of low to moderate relief trending N-S and NNE-SSW at W. Hawdayn and as scattered masses along W. Rahaba (Fig. 3). These rocks are mottled grey to greenish grey, weathered surface; heterogeneous suite with variable grain size and textures. Detailed field mapping of the basement rocks based on the field relations and structure observations, as well as, the petro graphical studies revealed that, the area include older granites (tonalities), younger granites (monzogranite) and pegmatite's (Fig. 4). The tonalite is grey in colour, highly exfoliated and forms low hills at the peripheries of the monzogranite. These rocks contain rounded to sub rounded xenoliths of diorite and 
amphibolite up to $30 \mathrm{~cm}$. There are intrusive contact between older granite and serpentinite (Fig. 5a) Monzogranite forms the main granitic masses of G. El Fereyid that is elongated in NW- SE directions (Fig. 4). Monzogranite is leucocratic, medium to coarse-grained, massive, jointed, exfoliated, pinkish grey in color and highly sheared. The fine granitic dykes are abundant dissecting the tonalite and monzogranite throughout the whole area especially at G. El Fereyid (Fig. 5b). El Fereyid monzogranite pluton is bounded from the west and south by W. Rahaba older granites and from the north by G. Marafai granites (Fig. 5c). The monzogranite dissected by a series of fault planes especially in the western side of the pluton, generally trending NW-SE direction and NE-SW and NW-SE trending basic, acidic dykes and quartz veins (Fig. 5d). Pegmatites occur as pockets and veins that crosscut monzogranite. Three different types of pegmatite have been defined based on their mineralogy and morphology. The first type of pegmatite is less abundant and found as an irregular body in the southern part of the area (Fig. 4). This muscovite-rich pegmatite is often very coarse grained and contains large individual crystals of its common constituents (Fig. 5e). It contains the highest radioelement concentrations compared to other rock units as determined from the in situ gamma ray spectrometric survey. The second type of pegmatite is found in the northwestern part of the mapped area, dissecting the monzogranite and it shows a NW - SE strike with variable dips (Fig. 5f). The third type is in the northern part of the area dissecting the tonalites and striking $\mathrm{E}-\mathrm{W}$. Pegmatite occurs as a vein type (granitic and perthitic pegmatites) hosted within the monzogranite. Structural analysis shows the presence of a prominent set of folds with axes striking WNW to NW and a less prominent set with pronounced ENE and NNW trends. The major and minor faults are mainly thrust, normal and strike slip faults (El Amawy, 1991). Structures throughout the whole of the studied area are dominated by a heterogeneous brittle to ductile deformation. The directional analysis of the automatically extracted lineament maps (Fig. 6) and (rose diagram, lineament bar diagram length and lineament bar diagram number (Fig. 7) explained that there are NW to WNW, ENE, NNW, NNE and N-S directions. This result matches with lineament maps based on detailed structural fieldwork in previous studies reflecting the effectiveness of ASTER GDEM data and derived hill shades in the lineament extraction process. Highly faulting plays an important role in facilitating the alteration processes through the circulation of both hydrothermal solutions and/or meteoric water causing enrichments in large ion lithophile elements like uranium and thorium. This explains the obvious relation between the lineament density and the presence of radioactive potentialities along with degree of alteration.

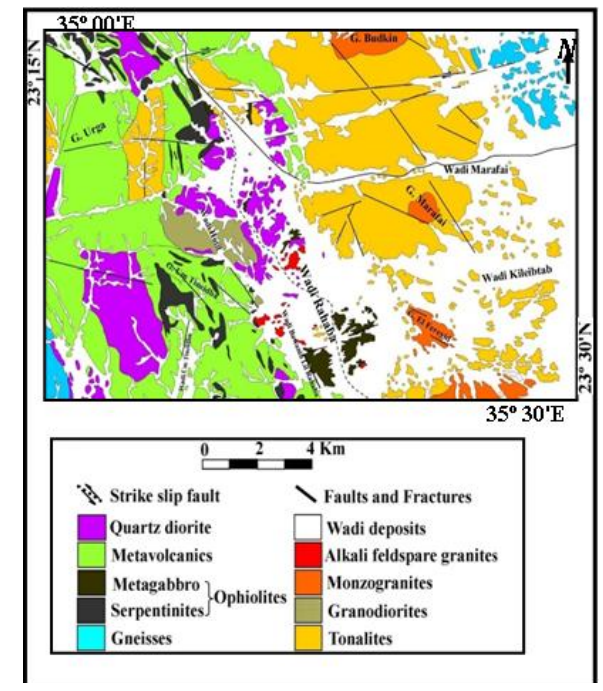

Fig. 3 Geologic map of G. El Fereyid - W. Rahaba area, South Eastern Desert, Egypt

\section{Analytical Methods}

The heavy minerals were separated using heavy liquid (bromoform) separation technique, followed by magnetic fractionation using Frantz isodynamic separator. The heavy minerals were picked under the binocular microscope and identified by X-ray diffraction techniques in the Laboratories of Nuclear Materials Authority (NMA).The concentration of equivalent uranium (eU) in ppm, equivalent thorium (eTh) in ppm, dose rate (D.R.) in nSvh-1 and potassium (K) in \% were determined using RS 230 instrument. 


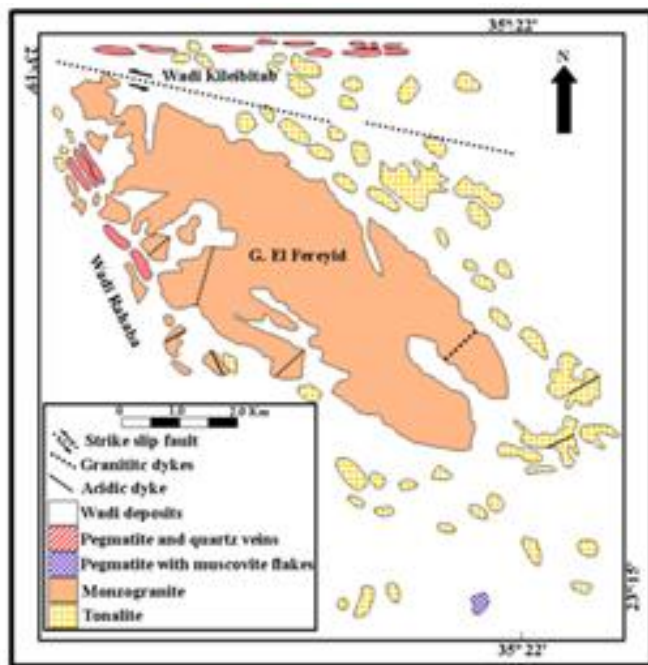

Fig. 4 Detailed geologic map of G. El Fereyid - W. Rahaba area, South Eastern Desert, Egypt (Modified after Abd El Naby and Saleh, 2003)

\section{Mineralogical InVESTIGATIONS}

The mineralogical studies of the monzogranite and pegmatites were performed on whole rock samples and separated mineral grains by petrographic microscope. Electron-Scanning Microscope (SEM) supported by EDX. Scanning electron microscope (SEM) with a back-scattered electron imaging (BSE) of the rocks of G.El Fereyid - W. Rahaba show that these rocks host to a numerous radioactive and nonradioactive minerals. Results of detailed mineralogical examination of these elements have been identified as follow:

\subsection{Thorite $\left(\mathrm{ThSiO}_{4}\right)$}

It is mainly found as an accessory mineral in different rock types and geological environments especially pegmatites, granites and hydrothermal deposits. In most cases, it is metamicted due to its radiogenic nature. It is highly radioactive mineral due to the existence of thorium as a common radioactive element and uranium as minor component. It is confirmed by ESEM techniques and contains $72.30 \%$ Th, 9.13\% U, 4.90\% Fe, 1.97\% Al and 11.00\% Si (Fig .8a).

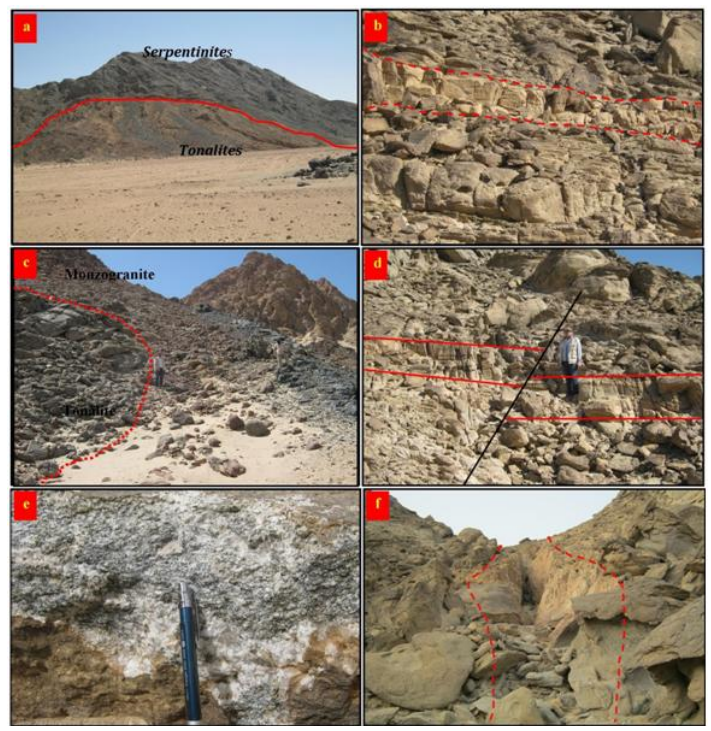

Fig. 5 View showing:- a) Intusive contact between serpentinites and tonalities of G. El Fereyid, SED, Egypt

(Looking N), b): Granitic dyke crosscut the monzogranites of G. El Fereyid, SED, Egypt. (Looking $\mathrm{NE}$ ), c): Intrusive contact between monzogranites and tonalites (Looking NW), d): N-S granitic dyke crosscut the monzogranites (Looking N), e): ): Pegmatites with flakes of muscovite crosscut the monzogranites of G. El Fereyid area, SED, Egypt. (Looking N), and f): Pegmatitic veins crosscut the monzogranites of G. El Fereyid - W. Rahaba area, SED, Egypt. (Looking N). 


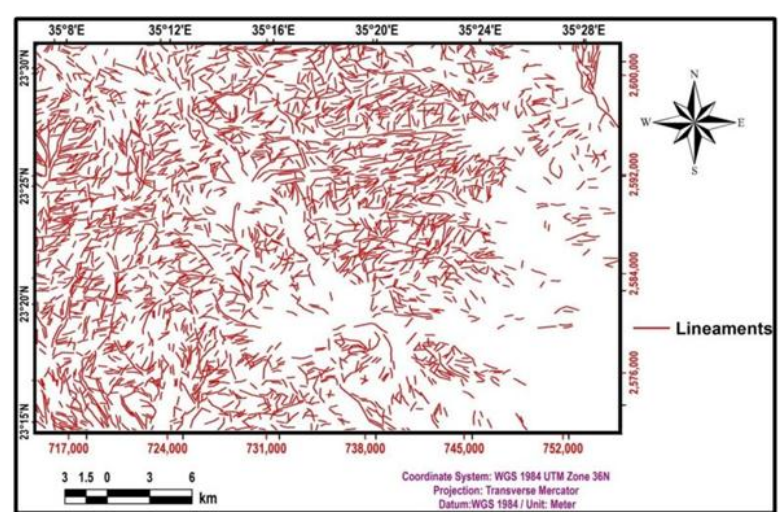

Fig. 6 Structural lineament map of G. El Fereyid - Wadi Rahaba area, SED, Egypt

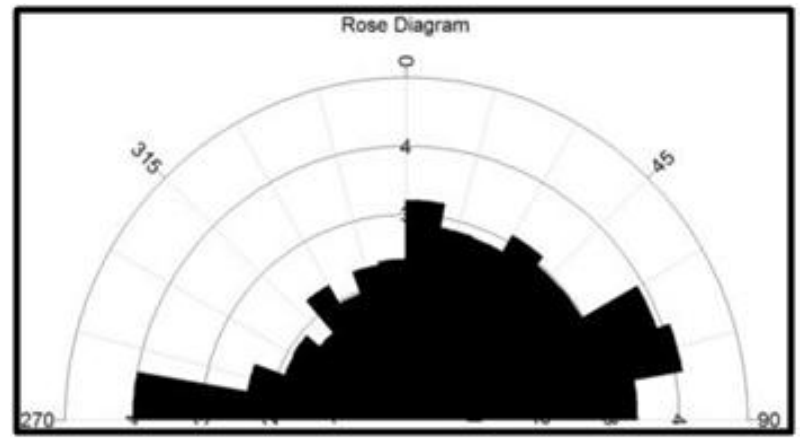

Fig. 7 Rose diagram showing the trends of faults of G. El Fereyid - W. Rahaba area, SED, Egypt

\subsection{Uranothorite [(Th, U) SiO4]}

Uranothorite is a variety of thorite minerals rich in uranium and only recorded in the pegmatites and monzogranite of G. El Fereyid - W. Rahaba area. The ESEM analysis shows that it consists essentially of $\mathrm{ThO}_{2}$, which exceeds significantly $\mathrm{UO}_{2}$. It is color black, to brown, with resinous to pitchy luster. Uranothorite may be occurring as inclusion in zircon. It is confirmed by ESEM techniques and contains $59.79 \% \mathrm{Th}, 15.16 \% \mathrm{U}, 19.04 \% \mathrm{Zr}, 3.01 \% \mathrm{Fe}, 1.97 \% \mathrm{Al}$ and $16.84 \% \mathrm{Si}$ (Fig.8b).

\subsection{Monazite [(Ce, La, Nd, Th) PO4]}

Monazite is an anhydrous phosphate mineral, principally of cerium and / or lanthanum, with lesser amounts of the heavier rare earths and is recorded as accessory mineral in both pegmatites and monzogranite. Monazite, which is one of the most common REEs bearing minerals, has a preferential selectivity towards the LREEs such as $\mathrm{Ce}, \mathrm{La}, \mathrm{Nd}, \mathrm{Sm}, \mathrm{Gd}$ and Eu. The monazite grains are commonly colorless and honey, however some monazite grains show brown to red colors with resinous luster. It is confirmed by ESEM techniques and contains $43.03 \% \mathrm{Y}, 43.33 \% \mathrm{P}, 3.44 \% \mathrm{Gd}$, $2.40 \%$ Dy, $2.19 \%$ La, $4.76 \%$ Th and $1.11 \%$ U (Fig. 8c).

\subsection{Zircon $(\mathrm{ZrSiO4})$}

Zircon was found as the most abundant accessory mineral in the studied rocks of G. El Fereyid - W. Rahaba area. Petrographically, zircon is present as prismatic, euhedral to subhedral crystals in many rock types. Some zircon crystals are metamicted and surrounded by dark pleochroic haloes of different shapes and sizes. Some crystals show corrosion, zonation and overgrowth phenomena. Zircon is represented by prismatic grains with bipyramidal faces or by broken crystals with one pyramid. Some grains with sub-rounded edges are recorded. It is confirmed by ESEM techniques and contains $30.99 \% \mathrm{Zr}, 62.93 \% \mathrm{Si}, 1.65 \% \mathrm{Ca}, 2.38 \% \mathrm{Fe}, 1.28 \% \mathrm{Hf}, 0.16 \%$ Th and $0.61 \% \mathrm{U}$ (Fig. 8d).

\subsection{Fergusonite (Nb, Y, Ta, U, Al, Mg, Fe, REE)}

Fergusonite is recorded as parent REE mineral in pegmatite of G. El Fereyid - W. Rahaba area. Fergusonite presents in the form of tabular prismatic shape which containing potential concentration of the high field strength elements (HFSE) such as Nb, Ta, and Ti, besides U (Fig. 8e). Fergusonite, ideally $\mathrm{YNbO}_{4}$, occurs as an accessory mineral in granitic pegmatites, mostly in rare earth element 
(REE)-enriched pegmatites (Ervanne, 2004, Ercit, 2005 and Reto et al., 2009), and often in combination with one or more $\mathrm{Y}, \mathrm{Th}, \mathrm{Nb}, \mathrm{Ta}$, Ti oxide accessory minerals (Lumpkin, 1998). It is confirmed by ESEM techniques and contains $45.28 \% \mathrm{Ti}, 15.93 \% \mathrm{Nb}, 0.55 \% \mathrm{Ta}, 8.11 \% \mathrm{Si}, 7.34 \% \mathrm{La}$, $2.77 \%$ Th and $9.60 \% \mathrm{U}$.

\subsection{Samarskite [(Y, Ce, U, Fe)3(Nb, Ta, Ti)5O16]}

Samarskite is common and locally abundant enough that it has potential to be valuable source of REEs. Samarskite has dark pitchy to velvety black to dark brown color, irregular massive grains with sub-conchoidal fracture. It is confirmed by ESEM techniques and contains $45.28 \% \mathrm{Ti}, 15.93 \% \mathrm{Nb}$, $0.55 \% \mathrm{Ta}, 8.11 \% \mathrm{Si}, 7.34 \% \mathrm{La}, 2.77 \%$ Th and $9.60 \% \mathrm{U}$ (Fig. 8f).

\subsection{Ishikawaite [(U, Fe, Ca, Y, Th) (Nb, Ta, Ti)2O6]}

Ishikawaite is recorded as accessory mineral in pegmatite of G. El Fereyid - W. Rahaba area. Ishikawaite is a member of the samarskite group (Hanson et al., 1999 and Simmons et al., 2006). It occurs as euhedral to subhedral crystals and ranges in size from 5 to $10 \mu \mathrm{m}$,but there are two phases, one is primary euhderal in nature and the other is a replacement with columbite minerals. They are distinguished by their bright notes in SEM-BSE images (Fig. 9a). It is confirmed by ESEM techniques and contains $20.92 \% \mathrm{U}, 3.71 \% \mathrm{Fe}, 2.16 \% \mathrm{Ca}, 14.71 \% \mathrm{Y}, 2.74 \% \mathrm{Th}, 30.50 \% \mathrm{Nb}, 1.82 \% \mathrm{Ta}$ and $14.72 \%$ Ti (Fig. 9a).

\subsection{Columbite [( $\mathrm{Fe}, \mathrm{Mn}, \mathrm{Mg})(\mathrm{Nb}, \mathrm{Ta}) 2 \mathrm{O6}]$}

Columbite is the most widespread niobium mineral and makes for an important ore of the industrially useful metal. Columbite also called niobite; it is black to dark brown tabular or prismatic crystals crystallize in orthorhombic system. Trace elements such as $\mathrm{Ta}_{2} \mathrm{O}_{3}$ has been reported in substantial amounts in columbite grains and attain $4.58 \mathrm{wt} \%$ (Fig. 9b). The columbite mineral is ferruginated, with $\mathrm{Fe}^{3+}$ content reaching up to $4.60 \mathrm{wt} \%$, while $\mathrm{MnO}$ is reported as $12.28 \mathrm{wt} \%$. It is confirmed by ESEM techniques and contains $71.87 \% \mathrm{Nb}$ and $4.58 \% \mathrm{Ta}$.

\subsection{Fluorite [Ca F2]}

Fluorite occurs in different geological environments particularly in granites and pegmatites, and it has close geochemical association with $\mathrm{U}$, Th and REEs. It is always recorded in the radioactive samples of the different rock units under consideration.

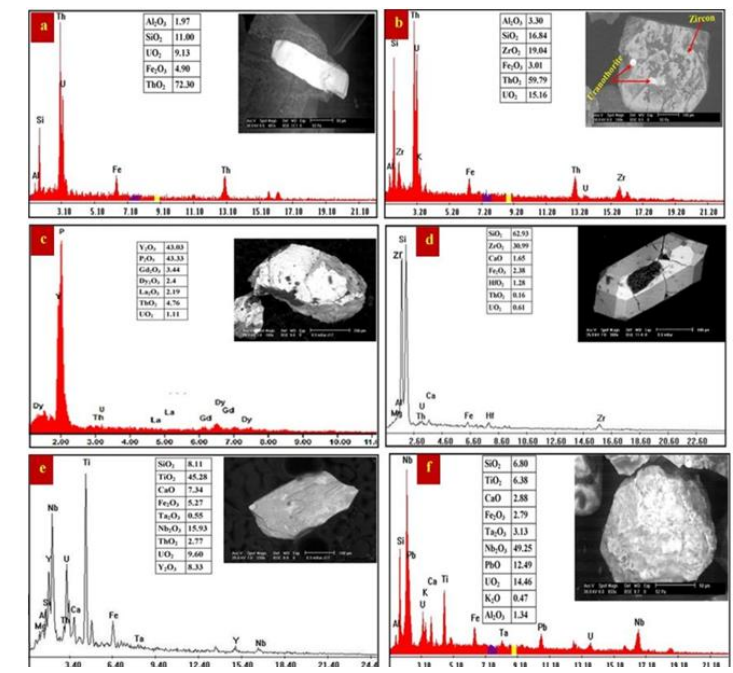

Fig. 8 ESEM image and EDX analysis data of:- a) Thorite mineral, b) Uranothorite mineral, c) Monazite mineral, d) Zircon mineral, e) Fergusonite mineral and f) Samarskite mineral from pegmatites and monzogranite of G. El Fereyid - W. Rahaba, South Eastern Desert, Egypt

Fluorite found in low temperature vein deposits. Fluorite crystals have irregular form with color varying from colorless, pale violet to dark violet (Fig. 9c). It is confirmed by ESEM techniques and contains $41.28 \%$ F, $57.51 \% \mathrm{Ca}$ and $1.87 \%$ Y (Fig. 9c).

\subsection{Allanite [(Ca, Ce, $\mathrm{La}) 2(\mathrm{Al}, \mathrm{Fe} 3+, \mathrm{Fe} 2+)$ 3O. SiO4. Si2O7. OH]}

It is one of epidote group which can incorporate significant amounts of $\mathrm{U}$, Th and LREEs. It characterizes accessory mineral composition in many types of granite and pegmatite, and is also 
common in hydrothermal veins. The allanite occurs as euhedral to subhedral grains, mostly elongated with tablet shape and pitchy to submetallic luster. The allanite grains are brownish black to black in color (Fig. 9d). It is mostly coated by iron oxides, and hence $\mathrm{Fe}_{2} \mathrm{O}_{3}$ is (4.64 wt \%). It is confirmed by ESEM techniques and contains 9.82\% Ca, 17.26\% Si, 6.50\% Al, 4.86\% La and 26.73 P (Fig. 9d).

\subsection{Titanite (CaTiSiO5)}

It is a calcium titanium silicate mineral $\left(\mathrm{CaTiSiO}_{5}\right)$ with sphenoid habit. The color of titanite is attributed to presence of $\mathrm{Fe}_{2} \mathrm{O}_{3}$ which is responsible for its brown color, where the yellow varieties being low in iron content while brown or black titanite may carry 1\%, or more, Fe2O3 (Deer et al., 1992) (Fig. 9e). It is confirmed by ESEM techniques and contains $13.9 \% \mathrm{Ca}, 14.3 \% \mathrm{Ti}, 22.8 \% \mathrm{Si}$, 4.90\% La, 5.3\% Nd and 3.9\% Ce (Fig. 9e).

\subsection{Pyrite [FeS2]}

Pyrite is the main sulfide mineral encountered in the study area. It is recorded as well developed cubic crystals with pale brass-yellow color commonly disseminated in the pegmatites and monzogranite. The identification of the sulfide mineral is performed by using ESEM investigation (Fig. 9f). It is confirmed by ESEM techniques and contains $69.8 \% \mathrm{~S}$ and $32.92 \% \mathrm{Fe}$ (Fig. 9f).

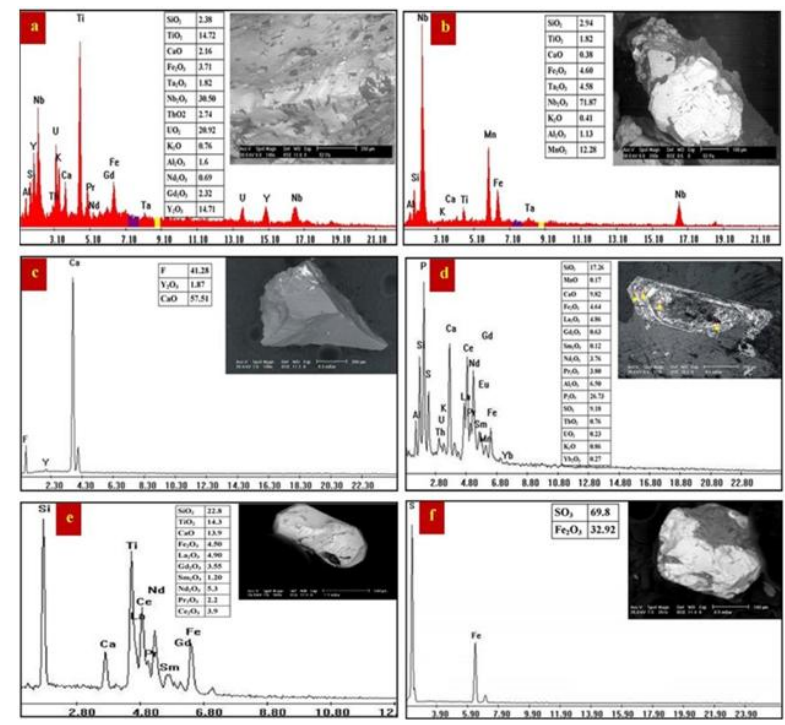

Fig. 9 ESEM image and EDX analysis data of:- a) Ishikawaite mineral b) Columbite mineral c) Fluorite mineral, d) Allanite mineral e) Titanite mineral and f) Pyrite mineral from pegmatites and monzogranite of $G$. El Fereyid - W. Rahaba, South Eastern Desert, Egypt

\section{SPECTROMETRIC Prospecting}

The instrument used in the ground $\gamma$-ray spectrometric survey measurements is RS-230 (Fig. 10). Ground $\gamma$-ray spectrometric survey can detect dose rate (D.R.) in unit (nSvh-1), potassium (K\%), equivalent uranium content (eUppm) and equivalent thorium content (eTh ppm). Uranium mobilization (eUm) in the studied rock types can be calculated as follows; the uranium mobilization is calculated the difference between the measured $\mathrm{eU}$ and the expected original uranium, which calculated by dividing the measured eTh by the average eTh/eU ratio in the crustal acidic rocks (original uranium $=\mathrm{eTh} / 3.5)$ to give the leaching values of uranium $(\mathrm{eUm}=\mathrm{eU}-\mathrm{eTh} / 3.5)$. Positive values indicate uranium addition by mobilization, whereas negative values indicated migration of uranium by leaching (Cambon, 1994). Table (1) shows the measured radiometric data were treated statistically to determine the distribution characteristics of the radioelements; $\mathrm{K}$ in $\%$, eU in ppm, eTh in ppm and their ratios in the different rock types in the study area. It also enables to define the relative degree of $\mathrm{U}$ mobilization.

Tonalites are characterized by lower radioactivity which ranges from 4.6 to 11.8 (m Sv/y) for D.R., from 1.5 to $3.7 \%$ for $\mathrm{K}$, from 1.7 to $5.6 \mathrm{ppm}$ for eU and from 4.9 to $12.8 \mathrm{ppm}$ for eTh. Moreover, it exhibits the ratio range from 0.2 to 1.0 for eU/eTh, 0.0 to 4.4 for eTh/K and from -1.0 to 3.7 for eU(eTh/3.5), the relationship between eU with $\mathrm{K} \%$, eTh with $\mathrm{K} \%$ and the $\mathrm{eU}$ with $\mathrm{U} / \mathrm{eTh}$ reflect a direct relation (Fig. 11). 
Gabal El Fereyid - Wadi Rahaba Area, South Eastern Desert, Egypt: Mineralization and Spectrometric Prospecting

Table 1. Summary of the statistics for the surface distribution of the three radioelements $K$, eU, eTh and their ratios for tonalites, monzogranites, granitic dykes, pegmatites and stream sediments for G. El Fereyid - W. Rahaba area, South Eastern Desert, Egypt

\begin{tabular}{|c|c|c|c|c|c|c|c|}
\hline & D.R.(mv/y) & $\mathrm{K} \%$ & $\mathrm{eU}(\mathrm{ppm})$ & eTh(ppm) & $\mathrm{eU} / \mathrm{eTh}$ & $\mathrm{eTh} / \mathrm{K}$ & eU-(eTh/3.5) \\
\hline \multicolumn{8}{|c|}{ Tonalites } \\
\hline $\operatorname{Mean}(\mathrm{X})$ & 8.8 & 2.8 & 3.3 & 8.3 & 0.4 & 2.9 & 1.0 \\
\hline Standard deviation $(\mathrm{S})$ & 1.4 & 0.6 & 0.9 & 2.0 & 0.2 & 0.8 & 1.1 \\
\hline Minimum & 4.6 & 1.5 & 1.7 & 4.9 & 0.2 & 0.0 & -1.6 \\
\hline Maximum & 11.8 & 3.7 & 5.6 & 12.8 & 1.0 & 4.4 & 3.7 \\
\hline $\mathrm{X}+3 \mathrm{~S}$ & 13 & 4.6 & 6 & 14.3 & 1 & 5.3 & 4.3 \\
\hline $\mathrm{X}-3 \mathrm{~S}$ & 4.6 & 1 & 0.6 & 2.3 & -0.2 & 0.5 & -2.3 \\
\hline No. of Reading & & & & 99 & & & \\
\hline \multicolumn{8}{|c|}{ Monzogranites } \\
\hline $\operatorname{Mean}(\mathrm{X})$ & 11.6 & 3.6 & 3.2 & 12.3 & 0.3 & 3.6 & -0.3 \\
\hline Standard deviation $(\mathrm{S})$ & 6.8 & 0.8 & 0.8 & 3.8 & 0.1 & 1.2 & 1.2 \\
\hline Minimum & 7.2 & 2.0 & 1.1 & 4.2 & 0.1 & 0.9 & -4.9 \\
\hline Maximum & 104.0 & 6.2 & 5.7 & 29.1 & 0.7 & 7.0 & 2.6 \\
\hline $\mathrm{X}+3 \mathrm{~S}$ & 32 & 6 & 5.6 & 23.7 & 0.6 & 7.2 & 3.3 \\
\hline $\mathrm{X}-3 \mathrm{~S}$ & -8.8 & 1.2 & 0.8 & 0.9 & 0 & 0 & -3.9 \\
\hline No. of Reading & & & & 202 & & & \\
\hline \multicolumn{8}{|c|}{ dykes } \\
\hline $\operatorname{Mean}(\mathrm{X})$ & 10.8 & 3.6 & 3.4 & 11.3 & 0.5 & 3.2 & 0.1 \\
\hline Standard deviation $(\mathrm{S})$ & 4.2 & 1.4 & 2.7 & 8.6 & 0.4 & 1.8 & 3.7 \\
\hline Minimum & 4.4 & 1.1 & 1.2 & 2.0 & 0.1 & 0.6 & -6.7 \\
\hline Maximum & 19.4 & 6.9 & 12.3 & 32.3 & 1.8 & 7.2 & 10.1 \\
\hline $\mathrm{X}+3 \mathrm{~S}$ & 23.4 & 7.8 & 11.5 & 37.1 & 1.7 & 8.6 & 11.2 \\
\hline $\mathrm{X}-3 \mathrm{~S}$ & -1.8 & -0.6 & -4.7 & -14.5 & -0.7 & -2.2 & -11 \\
\hline No. of Reading & & & & 66 & & & \\
\hline \multicolumn{8}{|c|}{ Pegmati } \\
\hline $\operatorname{Mean}(\mathrm{X})$ & 655.1 & 4.6 & 37.9 & 115.7 & 0.4 & 26.8 & 4.8 \\
\hline Standard deviation $(\mathrm{S})$ & 548.4 & 1.0 & 33.0 & 98.9 & 0.2 & 23.9 & 21.8 \\
\hline Minimum & 9.4 & 2.1 & 1.2 & 1.8 & 0.1 & 0.3 & -66.1 \\
\hline Maximum & 1800.0 & 7.1 & 149.0 & 375.0 & 1.5 & 113.5 & 87.6 \\
\hline $\mathrm{X}+3 \mathrm{~S}$ & 2300.3 & 7.6 & 136.9 & 412.4 & 1.0 & 98.5 & 70.2 \\
\hline $\mathrm{X}-3 \mathrm{~S}$ & -990.1 & 1.6 & -61.1 & 181 & -0.2 & -44.9 & -60.6 \\
\hline No. of Reading & & & & 185 & & & \\
\hline \multicolumn{8}{|c|}{ Stream sediments } \\
\hline $\operatorname{Mean}(\mathrm{X})$ & 328.9 & 3.4 & 11.4 & 35.2 & 0.3 & 10.8 & 1.4 \\
\hline Standard deviation $(\mathrm{S})$ & 190.6 & 0.7 & 5.3 & 14.7 & 0.1 & 6.1 & 4.4 \\
\hline Minimum & 65.0 & 1.7 & 2.0 & 7.0 & 0.1 & 3.5 & -14.4 \\
\hline Maximum & 834.0 & 5.0 & 25.0 & 96.0 & 1.1 & 45.7 & 17.7 \\
\hline $\mathrm{X}+3 \mathrm{~S}$ & 900.7 & 5.5 & 27.6 & 79.3 & 0.6 & 29.1 & 14.6 \\
\hline $\mathrm{X}-3 \mathrm{~S}$ & -242.9 & 1.3 & -4.5 & -8.9 & 0 & -7.5 & -11.8 \\
\hline No. of Reading & \multicolumn{7}{|c|}{86} \\
\hline
\end{tabular}

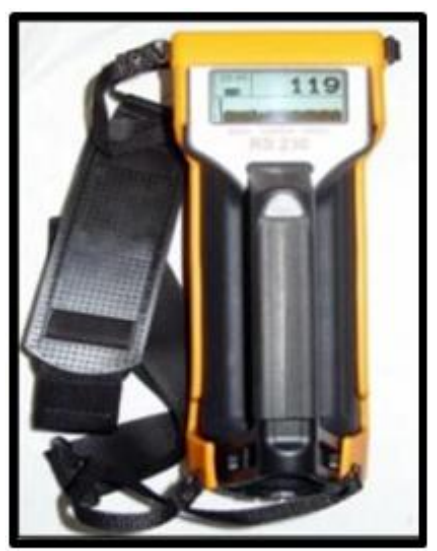

Fig. 10 Photograph showing portable gamma-ray spectrometer model RS-230 
Monzogranite is characterized by considerable radioactivity, which ranges from 7.0 to 104.0 (m Sv/y) for D.R., from 2.0 to $6.2 \%$ for $\mathrm{K}$, from 1.1 to $5.7 \mathrm{ppm}$ for eU and from 4.2 to $29.1 \mathrm{ppm}$ for eTh. Meanwhile, eU/eTh ratio ranges from 0.1 to 0.7 , eTh/K ratio ranges from 0.9 to 7.0 and $\mathrm{eU}-(\mathrm{eTh} / 3.5)$ ranges from -4.9 to 2.6, the relationship between $\mathrm{eU}$ with $\mathrm{K} \%$, eTh with $\mathrm{K} \%$ and the eU with U/eTh indicate positive correlation (Fig.12).

The monzogranite samples plotted on the K-eTh diagram can be classified into three groups (Fig. $16 \mathrm{~b}$ ); the first group shows low-K values (1 to 4.7\%) and a limited eTh range (7-20ppm). The second group is characterized by medium-K values (4.7 to 5\%) and high eTh range (20-29 ppm). The third group showing samples with $\mathrm{K} / \mathrm{eTh}$ ratios of about 2000 is characterized by contemporaneous decrease of eTh and increase K (5-10ppm eTh) and (5-6.2\%K), respectively. The K/eTh diagram shows a reverse relation between eTh and $\mathrm{K} \%$ in monzogranite due to the increasing of $\mathrm{Na} \%$ over $\mathrm{K} \%$ during the late albitization process (Fig. 16b).

Pegmatites have the highest radioactivity among all studied different rocks. They include a wide range of radioactivity constituents. 9.4 to 1800.0 (m Sv/y) for D.R., 2.1 to $7.1 \%$ for K, 1.2 to $149.0 \mathrm{ppm}$ for $\mathrm{eU}$ and from 1.8 to $375.0 \mathrm{ppm}$ for eTh and from -66.1 to 87.6 for eU-(eTh/3.5). Moreover, they also exhibit a wide ratio ranges from 1.0 to 1.5 for eU/eTh, 0.3 to 113.5 for eTh/K, this means that, this rock unit has very high $\mathrm{U}$ potential mobilization and its ratios are not normal and form anomalous zones, the relationship between eU with $\mathrm{K} \%$, eTh with $\mathrm{K} \%$, eU with D.r, eTh with D.r, eU with eU/eTh and K\% with D.r show negative linear distribution that means the eU/eTh ratio tends to increase with uranium mobilization and post magmatic redistribution in pegmatites (Fig. 13).

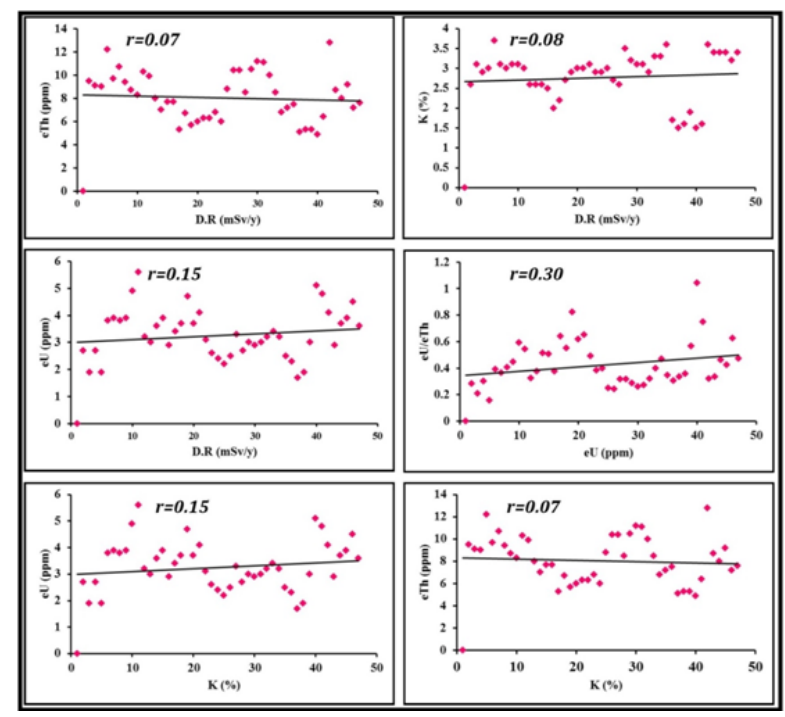

Fig. 11 Radioactive elements plots for ground gamma-ray spectrometry measurements of tonalite rocks at G. El Fereyid - W. Rahaba area, Southern Eastern Desert, Egypt

The pegmatite samples plotted on the K-eTh diagram can be classified into one group (Fig. 17b); shows high-K values (2.1 to $7.1 \%$ ) and high eTh (1.8-375ppm). The K/eTh diagram shows a reverse relation between eTh and $\mathrm{K} \%$ in pegmatite.

Granitic dykes are characterized by medium radioactivity which ranges from 4.4 to 19.4 (m Sv/y) for D.R., from 1.1 to $6.9 \%$ for $\mathrm{K}$, from 1.2 to $12.3 \mathrm{ppm}$ for eU and from 2.0 to $32.3 \mathrm{ppm}$ for eTh. Moreover, it exhibits the ratio range from 0.1 to 1.8 for eU/eTh, 0.6 to 7.2 for $\mathrm{eTh} / \mathrm{K}$ and from -6.7 to 10.1 for eU-(eTh/3.5). The calculated standard deviation represents low dispersion of the data around the mean value except for D.R, eTh as moderate values. The relationship between eU with $\mathrm{K} \%$, eTh with $\mathrm{K} \%$, eU with D.r, eTh with D.r, eU with eU/eTh and $\mathrm{K} \%$ with D.r show negative linear distribution that means the eU/eTh ratio tends to increase with uranium mobilization and post magmatic redistribution in granitic dyke (Fig. 15).

The granitic dyke samples plotted on the K-eTh diagram can be classified into three groups (Fig. $18 \mathrm{~b})$; the first group shows low-K values (1-3.3\%) and a limited eTh range (4-15ppm).The second group is characterized by medium-K values ( 3 to $5.2 \%$ ) and high eTh range (20-32ppm). The third group showing samples with $\mathrm{K} / \mathrm{eTh}$ ratios of about 4000 is characterized by contemporaneous decrease of eTh and increase K (4-10ppm eTh) and (3.9-6.9\%K), respectively. 


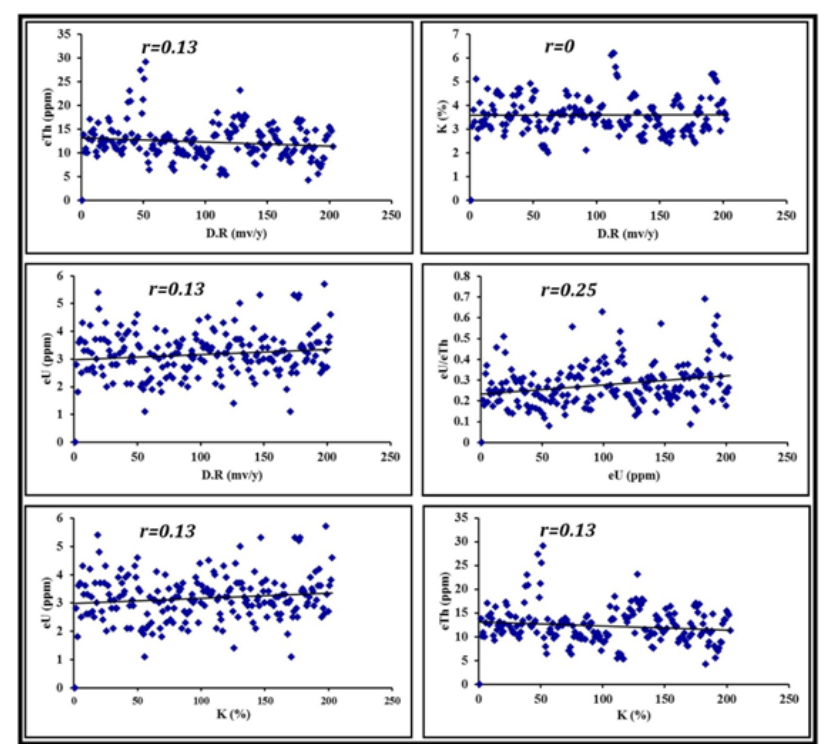

Fig. 12 Radioactive elements plots for ground gamma-ray spectrometry measurements of monzogranite rocks at G. El Fereyid - W. Rahaba area, Southern Eastern Desert, Egypt

Stream sediments are characterized by high radioactivity which ranges from 65.0 to 834.0 (m Sv/y) for D.R., from 1.7 to $5.0 \%$ for $\mathrm{K}$, from 2.0 to $25.0 \mathrm{ppm}$ for eU and from 7.0 to $96.0 \mathrm{ppm}$ for eTh and $\mathrm{eU}-(\mathrm{eTh} / 3.5)$ ranges from -14.4 to 17.7. Meanwhile, eU/eTh ratio ranges from 0.1 to $1.1, \mathrm{eTh} / \mathrm{K}$ ratio ranges from 3.5 to 45.7. The calculated standard deviation represents low dispersion of the data around the mean value except for D.R, eTh as moderate values, the relationship between eU with $\mathrm{K} \%$, eTh with K\%, eU with D.r, eTh with D.r and eU with eU/eTh show negative linear distribution, while the relation between K\% with D.r reflect a direct relation (Fig. 14). The stream sediment samples plotted on the K-eTh diagram can be classified into one group (Fig. 19b); shows medium-K values (1.7-5 and high eTh (7-96ppm).

The eTh/eU diagram (Figs. 16a, 17a, 18a and 19a) shows a direct relation between eTh and eU which means there is $U$ enrichment. Most of the samples are clustered in between 3.0 and $6.0 \mathrm{eTh} / \mathrm{eU}$ ratio with simultaneous increase in both $\mathrm{eU}$ and $\mathrm{eTh}$. Therefore, the uranium remained relatively immobile in the original rock. The highest $\mathrm{eU}$ and $\mathrm{eTh}$ values are related to the pegmatite sample. According to this model, the radioelement increase gradually during magmatic fractionation, but the ratio

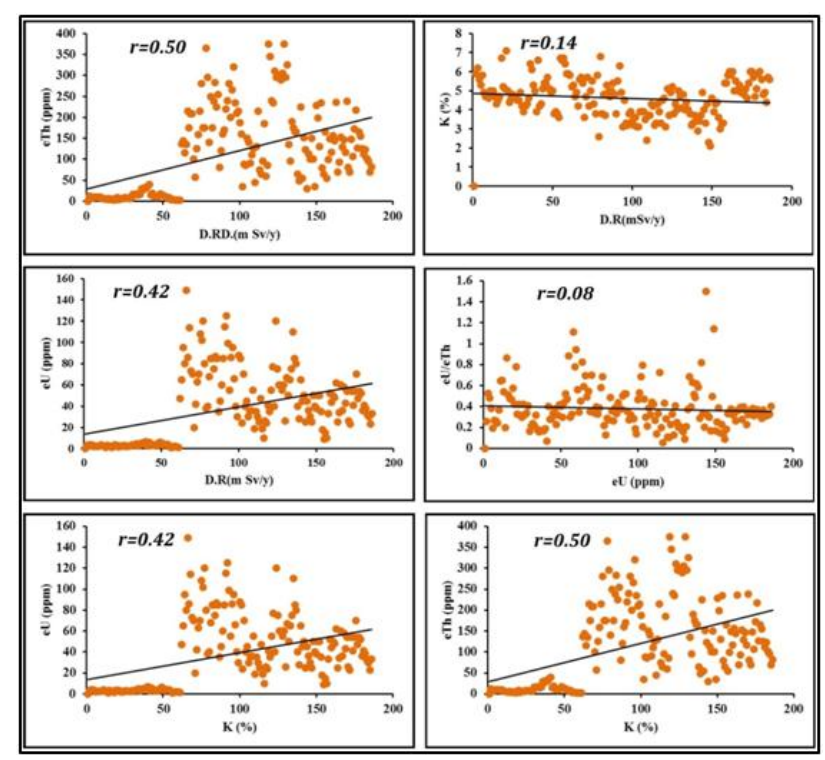

Fig. 13 Radioactive elements plots for ground gamma-ray spectrometry measurements of pegmatites at $G$. El Fereyid - W. Rahaba area, Southern Eastern Desert, Egypt

changes due to different alteration processes. The K/eTh diagram shows a reverse relation between eTh and $\mathrm{K} \%$ in tonalite. The eU/eTh versus eTh diagram (Fig. 16d, 17d, 18d and 19d) shows a 
reverse relationship, in which eU/eTh ratio increases with decreasing eTh for most plotted monzogranite, pegmatite, stream sediment and granitic dyke. On the other hand, the eU/eTh ratio versus eU diagram (Figs. 16c, 17c, 18c and 19c) shows a strong direct slope which indicates hydrothermal U enrichment. So, different alteration processes (kaolintization and hematitization) play an important role in $\mathrm{U}$ mobilization.

Figures (16e, 17e, 18e and 19e) show that different samples of monzogranite, pegmatite, granitic dyke and stream sediment have high $U$ content than that of the hypothetical $U$ distribution and so the mobilization gives positive values, which indicates that $U$ of these samples is leaching in. On the other hand, there are some samples have lower $\mathrm{U}$ content than that of the hypothetical U distribution and the mobilization show negative values, which indicate that $U$ of these samples is leaching out.

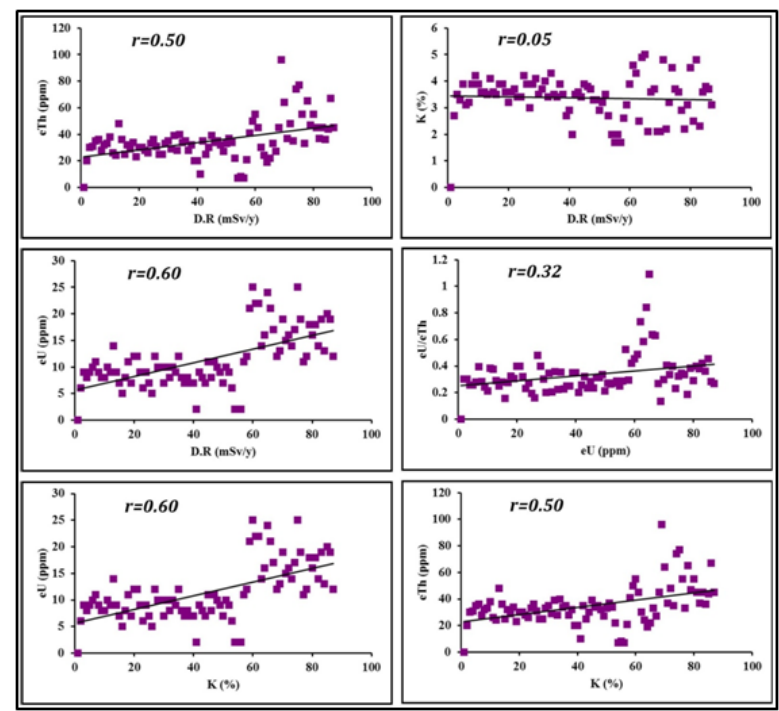

Fig.14 Radioactive elements plots for ground gamma-ray spectrometry measurements of stream sediments at G. El Fereyid - W. Rahaba area, Southern Eastern Desert, Egypt

\section{Equilibrium State Of RAdioactive ANOMALIES}

The equilibrium/disequilibrium state was discussed through calculation of the $\mathrm{D}$ - factor is equal to the ratio of the chemically determined uranium/radiometrically measured uranium (Hansink, 1976). If this factor is approximately unity, it indicates equilibrium state but if this factor is more or less than unity it indicates addition or removal of uranium, respectively (Stuckless et al., 1984). From the D factor of the monzogranite and pegmatite veins of the studied area presented in Tables (2), it is clear that chemical uranium is more than the radiometric uranium in all of the samples, which reflects disequilibrium due to the addition of uranium. This means that uranium has been transported recently and has not time to decay.

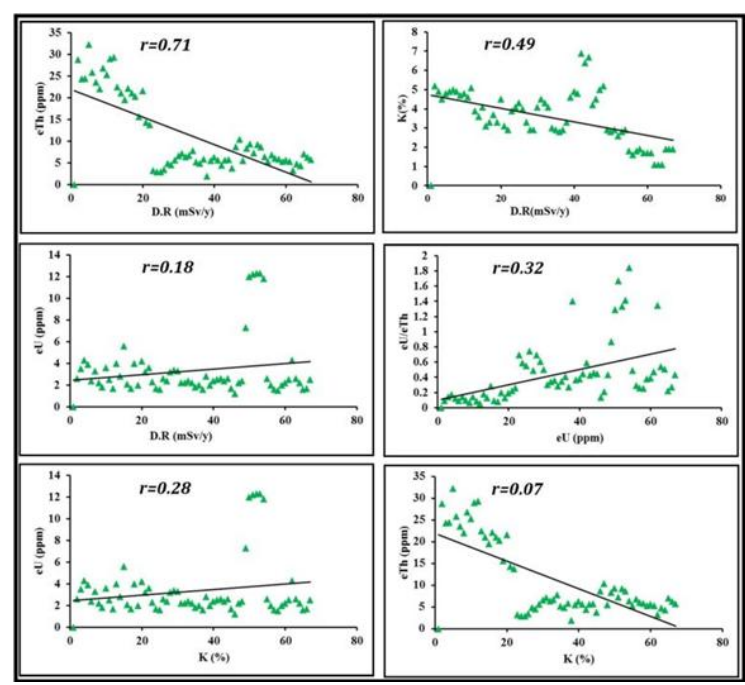

Fig. 15 Radioactive elements plots for ground gamma-ray spectrometry measurements of granitic dyke at G. El Fereyid - W. Rahaba - W. Rahaba area, Southern Eastern Desert, Egypt 
Gabal El Fereyid - Wadi Rahaba Area, South Eastern Desert, Egypt: Mineralization and Spectrometric Prospecting

Table 2. Results of eU-eTh spectrometric measurements (ppm) and U-Th (ppm) chemical analyses in monzogranites and pegmatites, G. El Fereyid - W. Rahaba area, SED, Egypt

\begin{tabular}{|c|c|c|c|c|c|}
\hline \multicolumn{6}{|c|}{ Monzogranites } \\
\hline Sample No. & $\mathrm{eU}(\mathrm{ppm})$ & eTh (ppm) & $\mathrm{U}(\mathrm{ppm})$ & Th (ppm) & U/eU (D-actor) \\
\hline F1 & 2.8 & 13.8 & 4.1 & 16.3 & 1.5 \\
\hline F11 & 1.5 & 10.1 & 2.2 & 11.7 & 1.5 \\
\hline F15 & 1.8 & 10.9 & 2.1 & 9.8 & 1.2 \\
\hline F24 & 3.7 & 10.0 & 4.8 & 13.2 & 1.3 \\
\hline F16 & 1.5 & 12.9 & 2.5 & 13.0 & 1.7 \\
\hline $\mathrm{F} 1$ & 2.3 & 17.1 & 2.7 & 20.6 & 1.2 \\
\hline $\mathrm{F} 35$ & 1.9 & 14.3 & 2.2 & 20.3 & 1.2 \\
\hline $\mathrm{F} 2$ & 3.6 & 12.6 & 5.7 & 29.1 & 1.6 \\
\hline F26 & 2.6 & 14.9 & 4.7 & 20.2 & 1.8 \\
\hline F3 & 3.3 & 13.8 & 3.7 & 25.6 & 1.1 \\
\hline F5 & 2.6 & 10.2 & 2.9 & 24.6 & 1.1 \\
\hline F36 & 4.2 & 9.2 & 5.6 & 23.3 & 1.3 \\
\hline F7 & 3.2 & 16.3 & 4.8 & 29.0 & 1.5 \\
\hline F18 & 2.7 & 11.4 & 3.3 & 28.7 & 1.2 \\
\hline F30 & 2.5 & 12.4 & 5.5 & 27.4 & 2.2 \\
\hline $\mathrm{F} 22$ & 3.7 & 13.1 & 4.9 & 22.3 & 1.3 \\
\hline F25 & 3.0 & 11.9 & 3.8 & 15.9 & 1.3 \\
\hline F17 & 3.8 & 10.6 & 5.1 & 28.6 & 1.3 \\
\hline F23 & 4.8 & 11.1 & 5.3 & 13.6 & 1.1 \\
\hline F33 & 3.7 & 12.7 & 4.5 & 26.9 & 1.2 \\
\hline \multicolumn{6}{|c|}{ Pegmatites } \\
\hline B27 & 25.0 & 55.0 & 28.5 & 215.2 & 1.1 \\
\hline $\mathrm{B} 23$ & 11.0 & 21.0 & 12.3 & 34.3 & 1.1 \\
\hline B13 & 42.0 & 125.0 & 44.6 & 85.8 & 1.1 \\
\hline B5 & 16.0 & 19.0 & 17.3 & 31.0 & 1.1 \\
\hline B11 & 4.2 & 50.9 & 6.9 & 60.3 & 1.6 \\
\hline $\mathrm{B} 25$ & 19.8 & 60.5 & 21.8 & 101.5 & 1.1 \\
\hline $\mathrm{B} 2$ & 37.2 & 122.6 & 41.0 & 167.1 & 1.1 \\
\hline B18 & 3.8 & 18.9 & 5.8 & 22.0 & 1.5 \\
\hline B15 & 22.9 & 89.2 & 30.9 & 109.5 & 1.3 \\
\hline B3 & 12.8 & 69.6 & 16.9 & 100.9 & 1.3 \\
\hline B20 & 20.8 & 102.3 & 33.9 & 119.6 & 1.6 \\
\hline B9 & 22.9 & 88.9 & 40.9 & 90.7 & 1.8 \\
\hline B30 & 21.6 & 95.9 & 31.0 & 110.6 & 1.4 \\
\hline
\end{tabular}

\section{Conclusions}

The basement rocks exposed in the area include tonalities, monzogranites and pegmatites. Tonalites are whitish grey to grey, medium to coarse-grained, variable strained, highly weathered and exfoliated and porphyritic texture. Monzogranite forms the main granitic masses of G. El Fereyid - W. Rahaba that is elongated in NW- SE directions. Monzogranite is leucocratic, medium to coarse-grained, massive, jointed, exfoliated, pinkish grey in color and highly sheared. The studied pegmatitic rocks occur as a vein type (granitic and perthitic pegmatites) hosted within the monzogranite.

Pegmatitic bodies of G. El Fereyid - W. Rahaba area associating the monzogranite contains radioactive minerals such as thorite, uranothorite, samarskite, Ishikawaite and fergusonite, besides the presence of some radioelements-bearing accessory minerals such as; zircon, monazite and fluorite.

Gamma-ray spectrometric measurements show that the pegmatitse and monzogranite possess the highest content of radioelements. The radioelement distributions are governed mainly by two magmatic phases. The older phase comprises tonalite and the associated E - W barren-pegmatite and quartz veins. It reflects the lowest concentration of $U$ and $T h$. The younger phase started with the intrusion of monzogranite and ended by emplacement of uraniferous pegmatite at the southern and northwestern part of the mapped area. The radiometric investigation indicates that the concerned uraniferous pegmatite is relatively enriched in eU and eTh relative to their hosting granites. The high $\mathrm{eU}$ and eTh contents are attributed to Th-mineralization and the presence of accessory minerals of 

Prospecting

radiogenic nature such as samarskite, uranothorite, fergusonite, thorite and zircon. The uranium and thorium mineralization in the radioactive pegmatite could be regarded as magmatic (syngenetic) as well as hydrothermal (epigenetic).

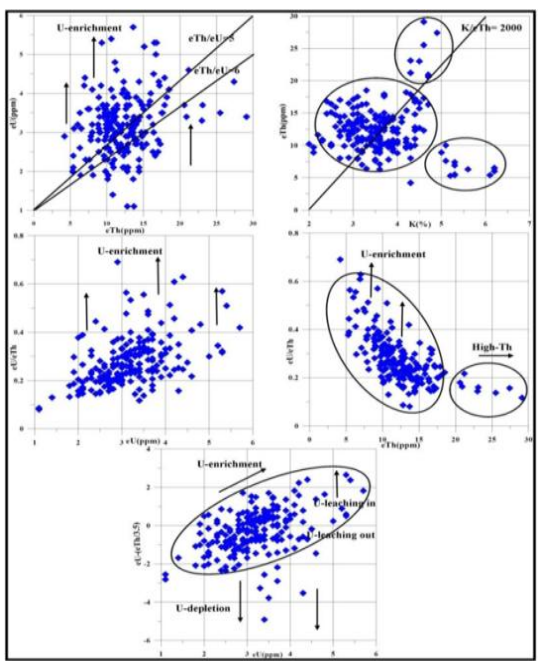

Fig. 16 Radioactive elements plots for ground gamma-ray spectrometry measurements of monzogranites at G. El Fereyid - W. Rahaba area, South Eastern Desert, Egypt

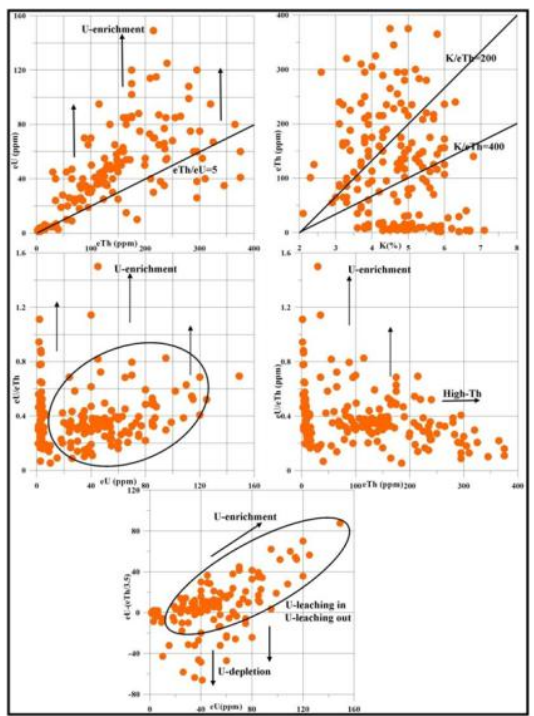

Fig. 17 Radioactive elements plots for ground gamma-ray spectrometry measurements of pegmatites at G. El Fereyid - W. Rahaba area, South Eastern Desert, Egypt

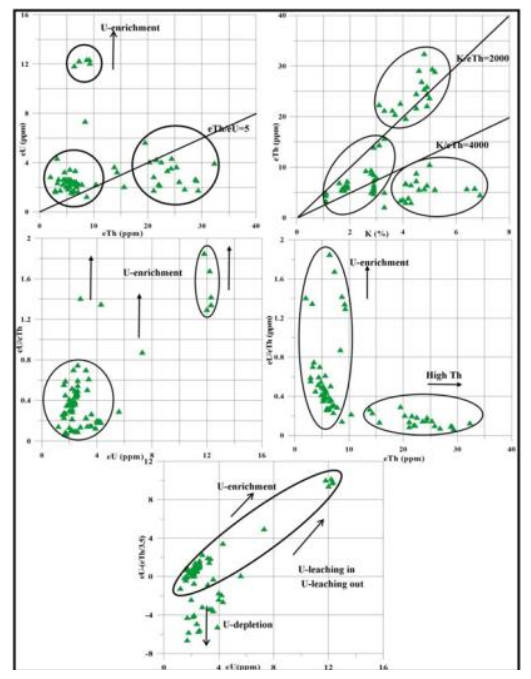

Fig. 18 Radioactive elements plots for ground gamma-ray spectrometry measurements of granitic dykes at G. El Fereyid - W. Rahaba area, South Eastern Desert, Egypt 


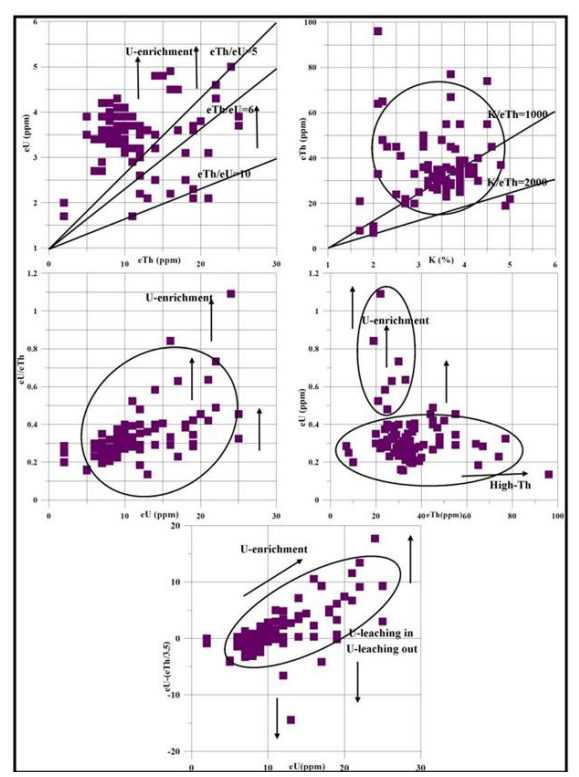

Fig. 19 Radioactive elements plots for ground gamma-ray spectrometry measurements of stream sediments at G. El Fereyid - W. Rahaba area, South Eastern Desert, Egypt

From the D-factor of the monzogranite and pegmatites veins of the G. El Fereyid - W. Rahaba area, it is clear that chemical uranium is more than the radiometric uranium in all of the samples, which reflects disequilibrium due to the addition of uranium. This means that uranium has been transported recently and has not time for decay. From the previous discussions and relationships, it can be concluded that, the magmatic differentiation played an important role in uranium distribution in the accessory minerals such as zircon and fluorite, but the post-magmatic process also played a very important role in concentrating uranium along fractures, joints and faults that maintained free movement of U-rich hydrothermal solution. The role of iron oxy-hydroxides in adsorbing $U$ from its circulating solution could not be neglected.

\section{ACKNOWLEDGMENTS}

The authors would like to thank the all my colleagues in the Department of Radioactive granitic deposits and association Abu Ramad project (2015-2018) for their help during the work and available facilities.

\section{REFERENCES}

[1] Abd El Naby, H.H and Saleh, G.M. (2003): Radioelement distribution in the proterozoic granites and associated pegmatites of Gabal El Fereyid area, Southeastern Desert, Egypt, Applied Radiation and Isotopes 59, p. 289-299.

[2] Abdel Karim, A.M; Sos, E.A. (2000): Geochemical characteristics and potassium argon ages dating of some granitoids from South Eastern Desert, Egypt. Egypt J Geol Soc Egypt, Cairo. Egypt V.44, No. 1, 2000, p. 305-318.

[3] Ali, M. A. (2001): Geology, petrology and radioactivity of Gabal El-Sibai area, Central Eastern Desert, Egypt. Ph.D Thesis, Cairo University.300pp.

[4] Cambon, A. R. (1994): Uranium deposits in granitic rocks. Notes on the national training course on uranium geology and exploration. Organized by IAEA and NMA, p. 8 - 20.

[5] El Amawy, M.A. (1991): Structure and tectonic development of Wadi Beitan, Wadi Rahaba area, South Eastern Desert, Egypt. 9th Symp Precambrian Develop, Nat Comitt Geol Sci, Cairo, Egypt, Feb 1991, P.9.

[6] El Baraga, M.H. (1992): Geolgical, mineralogical and geochemical studies of the Precamrian rocks around Wadi Rahaba, South Eastern Desert, Egypt. PhD Geol, Fac Sci, Tanta Univ, Egypt, 1992, 278pp.

[7] El Eraqi, M.A. F. (1992): Geophysical study on the area between Latitudes 23 00-25 N and Longitudes 33 30-35 30 E, Southeastern Desert, Egypt. PhD Geophy, Fac Sci, Zagazig Univ, 289 pp.

[8] Ercit, T.S. (2005): Identification and alteration trends of granitic-pegmatite-hosted (Y, REE, U, Th) - (Nb, Ta, Ti) oxide minerals: a statistical approach. The Canadian Mineralogist, Vol. 43, p.1291 - 1303.

[9] Ervanne, H. (2004): Uranium oxidation states in allanite, fergusonite and monazite of pegmatites from Finland. Neues Jahrbuch für Mineralogie Monatshefte, Vol. 7, p. 289 - 301. 
[10] Gaberlman, J.W., (1977): Migration of uranium and thorium exploration significance. American Association for Petroleum Geologists Bulletin, Studies in Geology No. 3, APPG, USA, 168pp.

[11] Gorman-Lewis, D., Burns, P.C. \& Fein, J.B. (2008): Review of uranyle mineral solubility measurements, J Chem. Thermodyn. 40, p. 335-352.

[12] Hansink, J. D. (1976): Equilibrium analyses of sandstone roll-front uranium deposits. International Atomic Energy Agency (IAEA), Vienna, p. 683 - 693.

[13] Hanson, S. L., Simmons, W. B., Faister, A. U., Foord, E.E. and Lichte, F. E. (1999): Proposed nomenclature for samarskite-group minerals, new data ishikawaite and calciosamaskite. Min. Mag., Vol. 63, p. 27-36.

[14] Ibrahim M.E., Saleh G.M., and Abd El-Naby H.H., (2001): Uranium mineralization in the two mica granite of Gabal Ribdab, South Eastern Desert, Egypt [J]. Appl. Radiat. Isot. 55/6, p.123 -134.

[15] Ibrahim, M.E., Shalaby, M.H., and Ammar, S.E., (1997): Preliminary studies on some uranium and thorium bearing pegmatites at G. Abu Dob, Central Eastern Desert, Egypt [J]. Proc. Egypt. Acad. Sci. 47, p. $173-188$.

[16] Lumpkin, G.R. (1998): Rare-element mineralogy and internal evolution of the Rutherford pegmatite, Amelia County, Virginia: a classic locality revisited. Canadian Mineralogist, Vol. 36, p. 339 - 353.

[17] Mandarino, J.A. (1999): Fleischer's Glossrey of Minerla Species. Mineralogical Record, Tucson, AZ, USA.

[18] Omar, S.A., (1995): Geological and geochemical features of the radioactive occurrences south G. Um Anab granitic masses, Eastern Desert, Egypt. M.Sc. Thesis, Cairo University, 164pp. Page, L.R., (1950): Uranium in pegmatites. Econ. Geol. 45, p.12 - 34.

[19] Plant, J.A., Simpson, P.R., Smith, B., and Windely, B.F. (1999): Uranium ore deposits-products of the radioactive Echo Bay U-Ni-Ag-Cu deposits, North West Territories, Canda. Economic Geology, 68, p. 635-656.

[20] Raslan, M..F., El Shall, H.E., Omar, S.A., and Daher, A.M., (2010): Mineralogy of polymetallic mineralized pegmatite of Ras Baroud Granite, Central Eastern Desert, Egypt [J]. Journal of Mineralogical and Petrological Sciences. 105 (3), p.123-134.

[21] Reto, G., Terry, W., Richard, W. and Katja, R. (2009): Metamict fergusonite-(Y) in a spessartine-bearing granitic pegmatite from Adamello, Italy. Chemical Geology, Vol. 261, p. 333 - 345.

[22] Rogers, J. J. W. and Adams, J. A. S. (1969): Uranium and thorium. In: Wedepohl. K.H. (ed), Handbook of geochemistry, New York, Springer Venleg, Vol. 4, pp., 92-B-1 to92-C-10.

[23] Sayyah,,T.A., Assaf, H.S.,A bdel Kader, Z.M.,Mahdy,M.A. and Omar,S.A., (1993): New Nb-Ta occurrence in Gebel Ras baroud, Central Eastern Desert, Egyptian Mineralogist, V.5, p. 41-55.

[24] Shurmann, H..M..E., (1966): The Precambrian along the Gulf of Suez and the Northern Part of the Red Sea $[\mathrm{M}]$. E.J. Brill, Leiden, Netherlands.

[25] Simmons W.B., Hanson S.L., and Falster A.U. (2006): Samarskite-(Yb) A new species of the samarskite group from the Litle Pasty pegmatite, Jefferson County, Colorado [J]. Can. Mineral. 44, p.1119 - 1125.

[26] Stuckless J. S., Bunker, C. M., Bush, C. A., Doering, W. P. and Scott, J. II. (1984): Geochemical and petrologic studies of a uraniferous granites of the Granite Mountains, Wyoming, U. Sll. Geol. Surv. Jour. Res. Vol. 5, p. $61-81$.

Citation: Gehad M. Saleh et.al, (2018). Gabal El Fereyid - Wadi Rahaba Area, South Eastern Desert, Egypt: Mineralization and Spectrometric Prospecting, International Journal of Mining Science (IJMS), 4(2), pp.1-15, DOI: http://dx.doi.org/10.20431/2454-9460.0402001

Copyright: (C) 2018 Authors. This is an open-access article distributed under the terms of the Creative Commons Attribution License, which permits unrestricted use, distribution, and reproduction in any medium, provided the original author and source are credited 